\title{
Характеристика госпіталізації населення в заклади охорони здоров'я спеціалізованої медичної допомоги Закарпатської області
}

\author{
ДВНЗ «Ужгородський національний університет», м. Ужгород, Україна
}

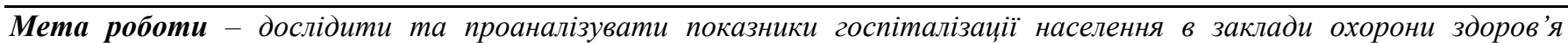
спеціалізованої медичної допомоги Закарпатської області.

Матеріали та методи. Матеріали: дані галузевої статистичної звітності по Закарпатській області за 2014,2017 та 2018 роки. Методи: медико-статистичний метод та метод структурно-логічного аналізу.

Результати. Встановлені рівні госпіталізачї дорослого та дитячого населення. Представлено структуру госпіталізації пацієнтів за класами хвороб.

Висновки. Результати дослідження необхідні для ефективного проведення реформи охорони здоров'я області. Ключові слова: Закарпатська область, населення, госпіталізація, показники.
\end{abstract}

\section{Вступ}

$\mathrm{B}$ країні проводиться реформування системи спеціалізованої медичної допомоги в тому числі стаціонарної [1]. Реформа передбачає формування госпітальних округів [2, 3] із створенням лікарень інтенсивного лікування [4], що передбачає скорочення ліжкового фонду та зміну системи госпіталізації пацієнтів. Все це відбувається на фоні зміни системи фінансування галузі із впровадженням гарантованого державою пакету безоплатної медичної допомоги [5].

Вказане і визвало необхідність проведення аналізу госпіталізації населення в заклади охорони здоров'я спеціалізованої медичної допомоги на рівні регіону.

Мета роботи - дослідити та проаналізувати показники госпіталізації населення в заклади охорони здоров'я спеціалізованої медичної допомоги Закарпатської області.

\section{Матеріали та методи}

Матеріалами дослідження служили дані галузевої статистичної звітності по Закарпатській області за 2014, 2017 та 2018 роки [6-8]. Під час проведення дослідження використано медико-статистичний метод та метод структурно-логічного аналізу.

\section{Результати дослідження та їх обговорення}

На початку дослідження було вивчено показники госпіталізації дитячого населення Закарпатської області в розрізі адміністративних територій та географічних зон за 2014, 2017, 2018 роки в розрахунку на 100 дітей. Отримані дані наведено в табл. 1.

Наведені в табл. 1 дані вказують на те, що в 2018 р. у зрівнянні з даними 2014 року статистично значущих змін в показниках госпіталізації дитячого населення не відбулося.

В розрізі адміністративних територій коливання показника складають 21,6 разів: від 1,23 в Мукачівському районі до 26,57 в м. Ужгород. Низький рівень госпіталізації дитячого населення в Мукачівському районі в заклади охорони здоров'я спеціалізованої медичної допомоги пояснюється функціонуванням в м. Мукачево обласної клінічної дитячої лікарні, а найбільш високі рівні госпіталізації дітей в м. Ужгороді пояснюються функціонуванням в місті міської дитячої лікарні в яку госпіталізуються діти і з найближчих районів.

Встановити різницю показника госпіталізації дітей в розрізі географічних зон області не вдалося.

Далі, в табл. 2, наведені показники госпіталізації дорослого населення Закарпатської області в розрізі адміністративних територій та географічних зон за 2014, 2017, 2018 роки в розрахунку на 100 дорослих.

Наведені в табл. 2 дані вказують на те, що в 2018 році у зрівнянні $з$ даними 2014 року статистично значущих змін в показниках госпіталізації дорослого населення, як і дитячого, не відбулося.

Коливання вказаного показника в розрізі адміністративних територій області складає 1,91 разів: від 9,24 в Ужгородському районі до 17,66 в Воловецькому районі.

Встановити різницю показника госпіталізації дітей в розрізі географічних зон області не вдалося. 
Таблиия 1

Показники госпіталізації дитячого населення Закарпатської області в розрізі адміністративних територій та географічних зон, 2014, 2017, 2018 роки (на 100 дітей)

\begin{tabular}{|c|c|c|c|c|}
\hline Адміністративні території, географічні зони & 2014 & 2017 & 2018 & 2018 до 2014 \\
\hline \multicolumn{5}{|c|}{ Низинна зона } \\
\hline м. Ужгород & 27,60 & 30,18 & 26,57 & $-1,03$ \\
\hline Берегівський район & 16,74 & 14,01 & 13,94 & $-2,80$ \\
\hline Виноградівський район & 14,38 & 14,99 & 14,06 & $-0,32$ \\
\hline Мукачевський район & 2,73 & 2,31 & 1,23 & $-1,50$ \\
\hline Ужгородський район & 8,15 & - & 7,88 & $-0,27$ \\
\hline \multicolumn{5}{|c|}{ Передгірська зона } \\
\hline Іршавський район & 10,86 & 10,87 & 9,67 & $-1,19$ \\
\hline Перечинський район & 13,31 & 12,80 & 12,55 & $-0,76$ \\
\hline Свалявський район & 12,83 & 11,97 & 13,71 & $+0,88$ \\
\hline Тячівський район & 9,57 & 8,52 & 8,77 & $-0,80$ \\
\hline Хустський район & 13,09 & 12,88 & 10,80 & $-2,28$ \\
\hline \multicolumn{5}{|c|}{ Гірська зона } \\
\hline Великоберезнянський район & 15,14 & 12,97 & 12,50 & $-2,64$ \\
\hline Воловецький район & 12,24 & 11,36 & 9,01 & $-3,23$ \\
\hline Міжгірський район & 11,29 & 10,25 & 13,99 & $+2,70$ \\
\hline Рахівський район & 14,14 & 12,84 & 12,41 & $-1,73$ \\
\hline
\end{tabular}

Таблиия 2

Показники госпіталізації дорослого населення Закарпатської області в розрізі адміністративних територій та географічних зон, 2014, 2017, 2018 роки (на 100 дорослих)

\begin{tabular}{l|c|c|c|c|c|}
\hline Адміністративні території, географічні зони & $\mathbf{2 0 1 4}$ & $\mathbf{2 0 1 7}$ & $\mathbf{2 0 1 8}$ & $\mathbf{2 0 1 8}$ до 2014 \\
\hline & Низинна зона & & & \\
\hline
\end{tabular}


В заклади охорони здоров'я спеціалізованої медичної допомоги м. Ужгорода госпіталізуються сільські жителі із найближчих до міста сільських районів.
Далі вивчалося питання за 2018 рік показників госпітальної захворюваності за класами хвороб. Отримані дані наведені в табл. 4.

Таблиия 3

Питома вага госпіталізованого сільського населення Закарпатської області в розрізі адміністративних територій та географічних зон, 2014, 2017, 2018 роки (\%)

\begin{tabular}{|c|c|c|c|c|}
\hline Адміністративні території, географічні зони & 2014 & 2017 & 2018 & 2018 до 2014 \\
\hline \multicolumn{5}{|c|}{ Низинна зона } \\
\hline м. Ужгород & 33,5 & 28,1 & 26,3 & $-7,2$ \\
\hline Берегівський район & 59,3 & 59,2 & 57,4 & $-1,9$ \\
\hline Виноградівський район & 64,3 & 57,9 & 64,6 & $+0,3$ \\
\hline Мукачевський район & 52,6 & 50,3 & 49,7 & $-2,9$ \\
\hline Ужгородський район & 69,8 & 72,7 & 73,6 & $+3,8$ \\
\hline \multicolumn{5}{|c|}{ Передгірська зона } \\
\hline Іршавський район & 89,2 & 89,3 & 89,3 & $+0,1$ \\
\hline Перечинський район & 74,7 & 74,9 & 75,6 & $+0,9$ \\
\hline Свалявський район & 60,2 & 57,8 & 58,5 & $-1,7$ \\
\hline Тячівський район & 70,4 & 69,2 & 70,6 & $+0,2$ \\
\hline Хустський район & 69,8 & 69,2 & 70,4 & $+0,6$ \\
\hline \multicolumn{5}{|c|}{ Гірська зона } \\
\hline Великоберезнянський район & 58,1 & 54,3 & 52,5 & $-5,6$ \\
\hline Воловецький район & 72,6 & 71,1 & 66,8 & $-5,8$ \\
\hline Міжгірський район & 72,1 & 86,5 & 71,1 & $-1,0$ \\
\hline Рахівський район & 60,2 & 55,0 & 54,1 & $-6,1$ \\
\hline
\end{tabular}

Таблиця 4

Показники госпітальної захворюваності за класами хвороб, 2018 рік

\begin{tabular}{|l|c|c|}
\hline \multicolumn{1}{|c|}{ Клас хвороб } & $\begin{array}{c}\text { Показник на 100 тис. } \\
\text { усього населення }\end{array}$ & $\begin{array}{c}\text { Частка, } \\
\mathbf{9}\end{array}$ \\
\hline Всього & 18134,1 & 100,0 \\
\hline Деякі інфекційні та паразитарні хвороби & 828,7 & 4,57 \\
\hline Новоутворення & 1361,2 & 7,51 \\
\hline Хвороби крові, кровотворних органів і окремі порушення із залученням & & 0,42 \\
\hline імунного механізму & 76,4 & 3,19 \\
\hline Хвороби ендокринної системи, розладу харчування, порушення обміну речовин & 577,9 & 3,77 \\
\hline Розлади психіки та поведінки & 683,0 & 3,29 \\
\hline Хвороби нервової системи & 597,2 & 2,28 \\
\hline Хвороби ока та його & 414,2 & 0,43 \\
\hline Хвороби вуха та соскового відростку & 78,2 & 17,76 \\
\hline Хвороби системи кровообігу & 3219,7 & 15,30 \\
\hline Хвороби органів дихання & 2775,3 & 10,62 \\
\hline Хвороби органів травлення & 1925,4 & 1,67 \\
\hline Хвороби шкіри та підшкірної клітковини & 302,4 & 5,47 \\
\hline Хвороби кістково-м'язової системи та сполучної тканини & 992,6 & 4,66 \\
\hline Хвороби сечостатевої системи & 845,4 & 1,20 \\
\hline Окремі стани, що виникають в перинатальному періоді & 217,4 & 0,99 \\
\hline Уроджені аномаіії (вади розвитку) & 179,2 & 6,61 \\
\hline Травми, отруєння та деякі інші наслідки дії зовнішніх причин & 1199,5 & \\
\hline
\end{tabular}


Наведені в табл. 4 дані вказують на те, що в структурі захворювань 3 якими були госпіталізовані пацієнти до закладів охорони здоров'я спеціалізованої медичної допомоги ведучи міста займають:

- хвороби системи кровообігу - 17,76\%;

- хвороби органів дихання - 15,30\%;

- хвороби органів травлення - 10,62\%;

- новоутворення - 7,51\%;

- травми, отруєння та деякі інші наслідки дії зовнішніх причин $-6,61 \%$.

\section{Висновки}

В розрізі адміністративних територій коливання показника госпіталізації дитячого населення складають 21,6 разів: від 1,23 в Мукачівському районі до 26,57 в м. Ужгород. Коливання показника госпіталізації дорослого населення в розрізі адміністративних територій області складає 1,91 разів: від 9,24 в Ужгородському районі до 17,66 в Воловецькому районі.

В 2018 році у зрівнянні з даними 2014 року статистично значущих змін в показниках госпіталізації дитячого населення не відбулося. Різниця показника госпіталізації як дітей так i дорослих в розрізі географічних зон області не встановлена.

Гранична різниця частки госпіталізованого сільського населення в розрізі адміністративних територій коливається в 1,79 разу: від 49,7\% в Мукачевському районі до 89,3\% в Іршавському районі.

В структурі захворювань 3 якими були госпіталізовані пацієнти до закладів охорони здоров'я спеціалізованої медичної допомоги ведучи міста займають: хвороби системи кровообігу - 17,76\%, хвороби органів дихання - 15,30\%, хвороби органів травлення $10,62 \%$, новоутворення $-7,51 \%$, травми, отруєння та деякі інші наслідки дії зовнішніх причин - 6,61\%.

Перспективи подальших досліджень пов'язані 3 вивченням якості надання стаціонарної медичної допомоги в закладах охорони здоров'я спеціалізованої медичної допомоги в розрізі адміністративних територій та географічних зон області.

\section{Література}

1. Національна стратегія реформування системи охорони здоров'я в Україні на період 2015-2020 років / Стратегічна дорадча група 3 питань реформування системи охорони здоров'я в Україні,. 2015. - 41 с. [Електронний peсурс]. Режим доступу: http://healthsag.org.ua/strategiya. - Назва з екрану.

2. Лехан B.M. Аналіз результатів реформування системи охорони здоров’я в пілотних регіонах: позитивні наслідки, проблеми та можливі шляхи їх вирішення / В.М. Лехан, Г.О. Слабкий, М.В. Шевченко // Україна. Здоров'я нації. - 2015. - № 3 (спеціальний випуск). - С. 67-86.

3. Слабкий Г.О. Уроки реформи охорони здоров'я в Україні: досягнення, невирішені питання, ризики, проблеми / Г.О. Слабкий, В.М. Лехан // Збірник матеріалів науково-практичної конференції 3 міжнародною участю «Організація і управління охороною здоров'я. 2015». - 20-21 жовтня 2015. - С. 26-27.

4. Пархоменко Г. Я. Лікарня інтенсивної допомоги - лікарня європейського зразка / Г. Я. Пархоменко // Вісн. соц. гігієни та орг. охорони здоров’я України. - 2011. - № 2. - С. 39-41.

5. Про державні фінансові гарантії медичного обслуговування населення: Закон України від 19 жовтня 2017 року № 2168-VIII [Електронний ресурс]. Режим доступу: http://search.ligazakon.ua/1_doc2.nsf/link1/T172168.html. Назва з екрану.

6. Мережа закладів та основні показники діяльності системи охорони здоров’я Закарпатської області за 2014 рік. Закарпатський обласний медичний інформаційно-аналітичний центр. Ужгород, 2015. - 110 с.

7. Мережа закладів та основні показники діяльності системи охорони здоров'я Закарпатської області за 2017 рік. Закарпатський обласний медичний інформаційно-аналітичний центр. Ужгород, 2018. - 140 с.

8. Мережа закладів та основні показники діяльності системи охорони здоров'я Закарпатської області за 2018 рік. Закарпатський обласний медичний інформаційно-аналітичний центр. Ужгород, 2019. - 152 с. 
Характеристика госпитализации населения в учреждения здравоохранения специализированной медицинской помощи Закарпатской области

Рогач И.М., Данко Д.В.

ГВУЗ «Ужгородский национальный университет»

Цель работы: исследовать и проанализировать показатели госпитализации населения в учреждения здравоохранения специализированной медицинской помощи Закарпатской области.

Материалы и методы. Материалы: данные отраслевой статистической отчетности по Закарпатской области за 2014, 2017 и 2018 годы. Методы: медикостатистический метод и метод структурно-логического анализа.

Результаты. Установлены уровни госпитализации взрослого и детского населения. Представлена структура госпитализации пациентов по классам болезней.

Выводы. Результаты исследования необходимы для эффективного проведения реформы здравоохранения области.

Ключевые слова: Закарпатская область, население, госпитализация, показатели.

\section{Characteristic of population hospitalization in health care institutions of specialized medical care in Transcarpathian region}

Rohach I.M., Danko D.V. Uzhhorod National University

Goal of research: to study and analyze the indicators of population hospitalization in health care institutions of specialized medical care in Transcarpathian region.

Materials and methods. Materials: data of sectoral statistical reporting in Transcarpathian region for the years 2014, 2017 and 2018. Methods: medico-statistical and method of structural-and-logical analysis.

Results. Levels of hospitalization of adult and pediatric population are defined. The structure of hospitalization of patients by classes of diseases is presented.

Conclusions. The results of study are necessary for effective healthcare reform.

\begin{tabular}{l}
\hline Key words: Transcarpathian region, population, \\
hospitalization, indicators.
\end{tabular}

\section{Відомості про авторів}

Рогач Іван Михайлович - доктор медичних наук, професор, звідувач кафедри соціальної медицини та гігієни УжНУ; 88001, м. Ужгород, пл. Народна, 3.

Данко Дана Валеріївна - кандидат педагогічних наук, доцент, доцент кафедри соціальної медицини та гігієни УжНУ; 88001, м. Ужгород, пл. Народна, 3. 